\title{
24 Land reform and land tenure for agricultural transformation in Southern Africa
}

\author{
Thulasizwe Mkhabela
}

\section{Introduction}

There is general consensus that land reform is an indispensable yet complicated process that is often loaded with multiple objectives, including economic, social and political underpinnings. Land reform in Southern Africa has been seized with the need to balance the tension between governments' tendencies to rationalize land acquisition and redistribution on the basis of historical injustices and political demands, on one hand, and the basis of valid economic and technical reasons of land reform, on the other hand (Bernstein, 2003). It should be stated that although the former reason for land reform is legitimate, it needs to be counterbalanced with the latter.

The land reform in Southern Africa can be construed broadly as having three distinct, yet related, pillars, as captured in Figure 24.1.

This chapter is particularly concerned with land reform as it pertains to agriculture and agricultural transformation, while recognizing that the land reform process is broader than just agriculture. The first pillar of land redistribution deals with the skewed access to and ownership of land, thus seeking more equitable access to land and ownership. The second pillar of land restitution seeks to return land ownership to people who were previously dispossessed of their land, particularly during colonization and displacement by settler communities. The third pillar includes reforms of existing land tenure systems to facilitate increased security of tenure and an increased sense of land ownership for selfdetermination of the people.

Despite a declining share in gross domestic product (GDP), agriculture remains a key sector in the economies of Southern African countries. Agriculture is a major employer and foreign exchange earner for most of countries in Southern Africa. Many people in Southern African countries still reside in rural areas, and their main economic activity is farming, predominantly smallholder agriculture.

In Southern Africa, land tenure reform must address a suite of problems brought about by colonization and dispossession. Moreover, pressures of high population growth, deteriorating natural resource base due to degradation, specific food shortages (increasing localized food insecurity incidences) and 


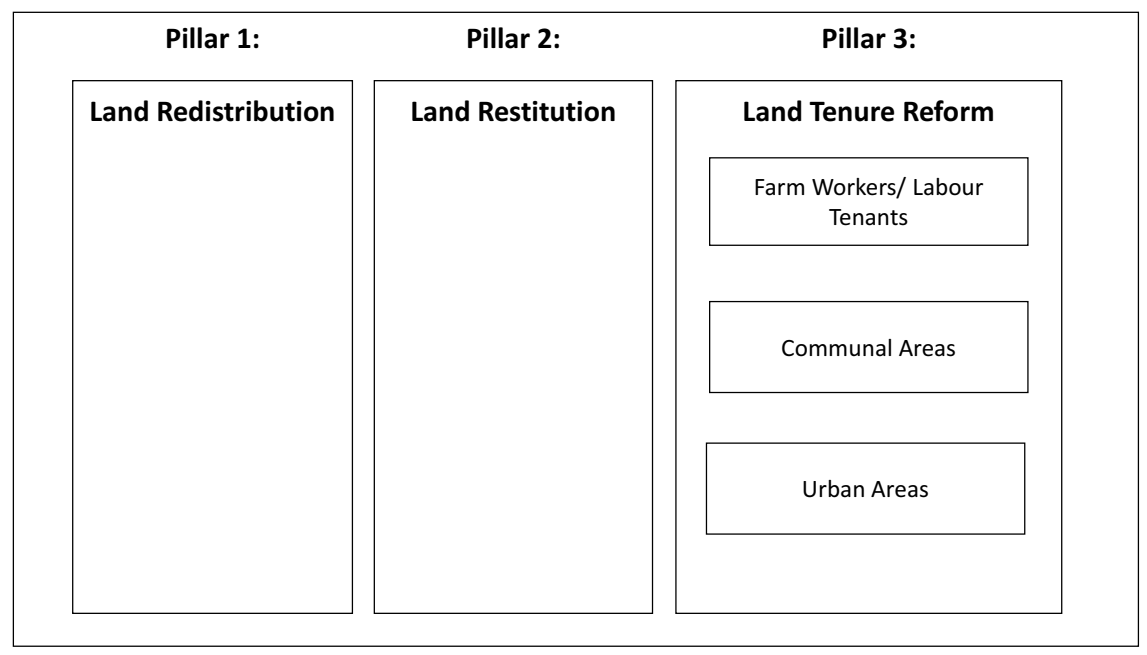

Figure 24.1 Land reform in Southern Africa

conflict over land use have given impetus to the raging debate and contestation on land reform in Southern Africa (Mkhabela, 2006).

The issue of tenure, the ownership or access to a piece of land has long been recognized as a critical factor for security, agricultural transformation, investment and conservation because it determines the linkages between responsibilities and authority over land and natural resources and also incentive structures for sustainable use (Murphree, 1996).

A brief explanation on what land tenure is will be presented before delving deep into a discussion on current land tenure systems in the Southern Africa region. Land tenure can be defined as the "terms and conditions on which land is held, used and transacted" (Adams et al., 1999), whereas, land tenure reform refers to a planned and deliberate change in the terms and conditions, such as the adjustment of the terms of contracts between land owners and tenants or the conversion of more informal tenancy into formal property rights. The fundamental goal of land tenure reform is to enhance and secure people's rights. Such changes are essential to avoid arbitrary evictions and the resultant landlessness. Furthermore, enhanced security of tenure is necessary for land rights holders to invest in the land and use it sustainably.

\section{Prevalent land tenure systems in Southern Africa}

There can be no doubt that tenure security matters and it has long been posited that tenure insecurity adversely affects agricultural productivity thereby constraining transformation in this sector of the economy. Land tenure in Southern Africa can be broadly divided into two categories, namely: 1) communal land tenure and 2) private land ownership, often referred to as freehold or title deed. 
An examination of land tenure systems needs to take into consideration the complete physical, socioeconomic, political and cultural background and context of the society as a whole. Suffice to say that the present land tenure systems of Southern Africa are a product of historical forces (Mushala et al., 1998). Figure 24.2 summarizes the complexity of land tenure priorities for Southern African households by showing that land rights, and land tenure reform by extension, are a continuum rather than a discontinuity process. Moreover, there is a prevalent coexistence with the formal system of a customary system of land holding and statutory land rights across Southern Africa (Bah et al., 2018). This coexistence has partially given rise to multiple, parallel and, often, even overlapping and contradictory land tenure regimes.

Communal land tenure in Southern Africa is premised on traditional leaders administering land in trust for the benefit of traditional communities residing on such land and for the purpose of promoting the economic and social development of the people. Generally, the communal land tenure system is biased against women and is perceived to carry substantial patronage; thus, it is subject to abuse by the traditional leadership and people that are well-connected - the rural elite. Furthermore, rural folk find it difficult to raise capital for investment into agricultural production on the land that they do not own.

There have been several attempts to remedy the phenomenon of land tenure insecurity in the region. Several traditional leaderships in Southern African countries that have been administering land in trust, have been issuing permission to occupy (PTO) certificates. PTOs are legal documents used to regulate business establishments in communal areas, but these are now being phased out in most Southern African countries. Permission to occupy certificates are being converted into Rights of Leasehold, which are more secure and can be

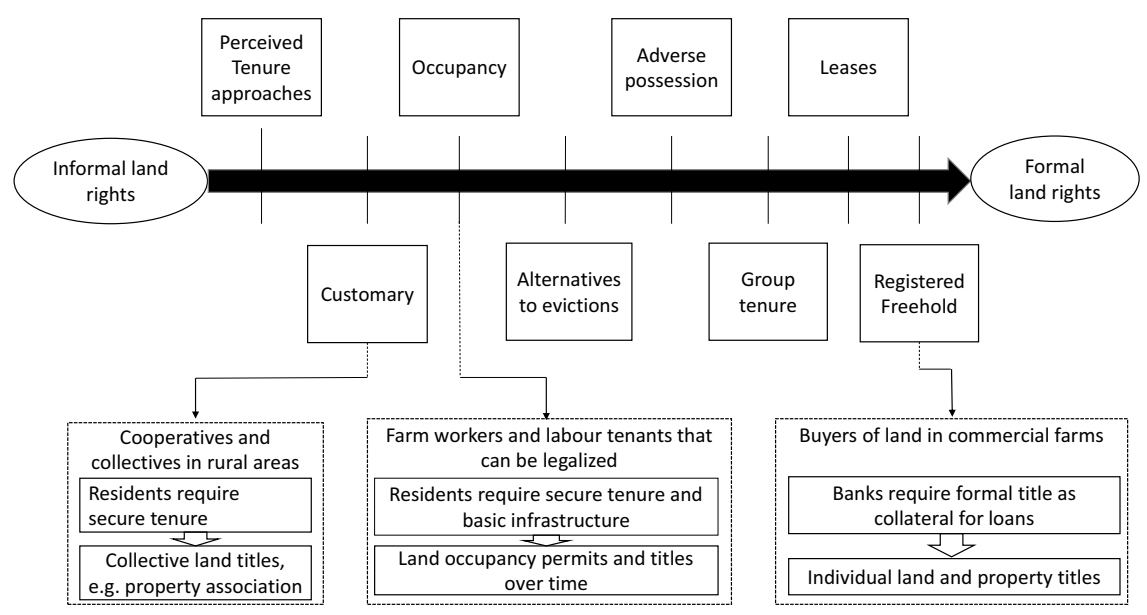

Figure 24.2 Land titling priorities for selected households

Source: Adapted from UN-Habitat's continuum of land rights (UN-Habitat, 2012) 
used as collateral by holders to acquire loans if the lease is for periods of ten years or more.

\section{Policies, processes and strategies for agricultural transformation through land reform}

Land reform, including tenure reform, can be used as a policy instrument to engender inclusive agribusiness value chains by changing the ownership structure of land, thereby affecting the access to land and produce. This dynamic land reform policy environment creates a dependency for land and produce of large agribusinesses on smallholder indigenous communities as new landowners, indirectly stimulating the establishment of joint ventures, sometimes referred to as inclusive businesses (Mkhabela, 2018; Chamberlain and Anseeuw, 2018).

Land reform and tenure policies should include:

- Security of tenure rights over individual and public lands

- Redistribution of land possession, to include the poor and deprived majority

- Improved land governance

- Enhanced transparency.

Southern African governments and policymakers should look at innovative approaches to land tenure reforms in order to respond to contemporary issues related to security of tenure and agricultural transformation. One such approach is the flexible land tenure system (FLTS). The FLTS is an innovative concept to provide affordable security of tenure to inhabitants in rural areas and informal settlements, which is being piloted in Namibia. The basic tenets of the FLTS is to establish an interchangeable $\mathrm{e}^{1}$ tenure registration system parallel and complimentary to the current formal system of freehold tenure. This approach is somewhat similar to the PTO system used by traditional leaders in rural Southern Africa, although the latter is less formal, as there is no registration of title deed. This approach has already had some successes in Southern Africa. For instance, Botswana has had considerable progress in tenure reform through the integration of traditional tenure with a modern system of land administration for both customary and commercial forms of land use (Adams et al., 1999).

In some Southern African countries, such as the rural KwaZulu-Natal province of South Africa, local rural people are finding other innovative ways of dealing with land tenure issues. There is an emerging approach whereby people exchange communal tenure rights with each other at a fee, with the traditional leadership's endorsement. This approach frees agricultural land to be used by alternative users other than the households that were initially allocated the piece of land.

\section{Conclusions}

It has been shown that countries with historically more equitable land distribution achieved growth rates two to three times higher than their counterparts 
with less equitable land distribution (World Bank, 2006, 2007). Furthermore, there is no doubt that successful land reform which does not result in deleterious economic disruption creates rapid economic growth, as has been demonstrated elsewhere in the world and accordingly documented (Knying, 2009; Laurie, 2016; Lodge, 2018). Against the foregoing assertions, it follows that a redistributive land reform would help reduce rural, and even urban, poverty.

However, there is a caveat. A poorly designed and implemented land reform process intended to unlock the economic assets of communal land by activating dead capital should be demand driven. An indiscriminate supply of tradable tenure in the communal areas may result in destitution of many rural people as an unintended consequence.

It can be concluded that one of the fundamental challenges facing the issue of land reform is ownership or more accurately the best form(s) of tenure systems, arrangements and structure that should apply in Southern Africa. The often misunderstood and even misrepresented notion that the best and only recognizable form of land tenure systems that should pervade is that of outright ownership, especially as it relates to agricultural transformation. This ownership can and does take different forms but is best represented by the fact that the owner (in whatever form or shape, i.e., individual, private company, public company, the government, trust, Community Property Association (CPA), etc.) is recognized by having a registered title to the land. The main problem with this theory, that all land tenure arrangements should be in the form of some direct or indirect ownership, is not shared or even appreciated - as fact - by the vast majority of mainly rural based indigenous south Africans. Most majority of these mainly rural, peri-urban and increasingly urban (townships and sprawling squatter camps) citizens are crying out for some form of enfranchisement and recognizing access to and the rights to land as being at the centre of their most basic of rights, and the lack of it is a serious impediment to agricultural transformation.

\section{Note}

1 Flexible in the sense that it is at the discretion of the land authorities to choose the appropriate type of tenure for the formalization of an informal settlement; interchangeable in the sense that the different tenure types provided for in the parallel registries can be upgraded; and parallel to the existing freehold registration system in the sense that parallel institutions will be responsible for the registration of different tenure types.

\section{References}

Adams, M., Sibanda, S. and Turner, S. (1999) Land tenure reform and rural livelihoods in southern Africa. Natural Resource Perspectives, p. 39. London: An Overseas Development Institute (ODI) publication. ODI.

Bah, El-hadj M.B., Faye, I. and Geh, Z.F. (2018) Unlocking land markets and infrastructure provision. Housing Dynamics in Africa, pp. 109-158. London: Palgrave Macmillan.

Bernstein, H. (2003) Land reform in Southern Africa in world - historical perspective. Review of African Political Economy 30(96): 203-226. 
Chamberlain, W.O. and Anseeuw, W. (2018) Inclusive business and land reform: Corporatization or transform? Land 7(1): 18-35.

Knying, K. (2009) The legacy of white highlands: Land rights, ethnicity and the post-2007 election violence in Kenya. Journal of Contemporary African Studies 27(3): 325-344.

Laurie, C. (2016) The Land Reform Deception: Political Opportunism in Zimbabwe's Land Seizure Era. Oxford: Oxford University Press.

Lodge, T. (2018) Thinking about South Africa land reform. Focus 83: 4-13.

Mkhabela, T. (2006) Impact of land tenure systems on land conflicts: Swaziland- a country case study. Africanus 36(1): 50-74.

Mkhabela, T. (2018) Dual moral hazard and adverse selection in South African agribusiness: It takes two to tango. International Food and Agribusiness Management Review 21(3): 391-406.

Murphree, M.W. (1996) Wildlife in Sustainable Development: Approaches to Community Participation. Paper presented to the ODA African Wildlife Policy Consultation. Sunningdale, UK.

Mushala, H.M., Kanduza, A.M., Simelane, N.O., Rwelamira, J.K. and Dlamini, N.F. (1998) Dual tenure systems and multiple livelihoods: A comparison of communal and private land tenure in Swaziland. Land Reform 2: 100-110.

UN-Habitat. (2012) Handling Land: Innovative Tools for Land Governance and Secure Tenure. United Nations Human Settlements Program. Nairobi: Kenya.

World Bank. (2006) The Rural Investment Climate: It Differs and It Matters. Washington, DC: World Bank.

World Bank. (2007) World Bank Development Report 2008: Agriculture for Development. Washington, DC: World Bank. 